\title{
17 From Locomotives to Libraries at Wildau Technical University, Germany
}

\begin{abstract}
The Hochschulbibliothek/Library of the Technische Hochschule Wildau/Technical University of Applied Sciences Wildau (TH Wildau) is housed in Hall 10, a former locomotive shed constructed in 1920 and located on the former industrial site of the Schwartzkopff factory south of Berlin, Germany. The complexity and demands of accommodating the multiple functions of the library along with the historic protection of the building made the project especially challenging. The University required a $21^{\text {st }}$ century academic library combined with a canteen and café housed in a listed building. The underlying philosophy for the architects was to retain the character, spatial quality and structural integrity of the original building while creating a new, interpretive architectural expression for the extension and renovation. New materials and techniques echoed and complemented the old. Inexplicably the final bay of the former locomotive shed was never completed and the new project a century later was able both to return the building to its original length and symbolically mark the new use as a library. The library moved from uninspiring and inadequate quarters to a stunningly restored building in an imposing site that was full of character and had an ambience that was a great draw for users. For the librarians, the project provided the opportunity to raise the library's profile, introduce new services through the exploitation of innovative technologies, and embrace a whole range of state-of-the-art uses, events and cooperative ventures. Advantages and drawbacks of the project are discussed and the benefits of reusing a historic building for a modern academic library are highlighted.
\end{abstract}

Keywords: Academic libraries - Germany; Library buildings - Design and construction; Engine houses (Railroads) - Remodelling for other use

\section{Introduction}

The town of Wildau, south of Berlin, was established in 1900 through the construction of the Schwartzkopff-Werke, a large factory area for locomotive construction which included a new town with an urban infrastructure and housing for its staff and workers. Since then, it has continued to grow and develop despite the traumatic effects of two World Wars and east German socialism. From the second half of the century, a new use as a site for academic training and its associated infrastructure has emerged. The campus of the Technische Hochschule

2 Open Access. (2021 Robert Niess and Frank Seeliger, published by De Gruyter. (cc)BY-NC-ND This work is licensed under the Creative Commons Attribution-NonCommercial-NoDerivatives 4.0 International License. https://doi.org/10.1515/9783110679663-018 


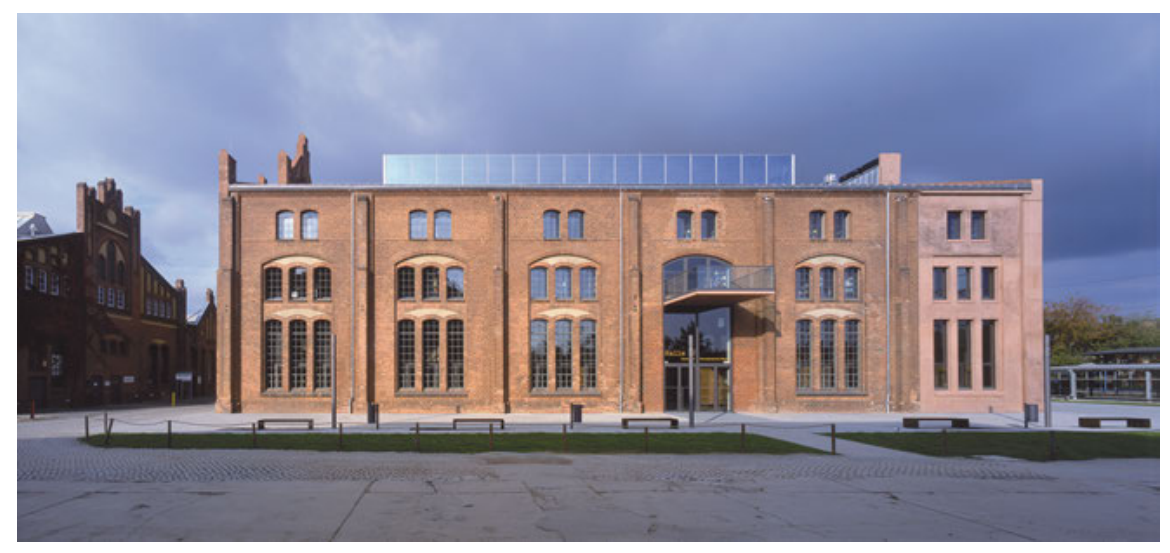

Fig. 1: Hall 10 as the new library. (c) Werner Huthmacher.

\section{Facts and Figures}

Name: Hochschulbibliothek/Library, Technische Hochschule Wildau/Technical University of Applied Sciences Wildau

Address: Hochschulring 1, 15745 Wildau, Germany

Website: https://www.th-wildau.de/hochschule/zentrale-einrichtungen/

hochschulbibliothek/

Opening: 2007

Architects: Chestnutt_Niess Architekten BDA http://www.chestnutt-niess.de/

Gross floor area: 4,265 m²

Main floor space: 2,320 m²

Collection size: 100,000

Staff: 8

Workstations: 150

Building costs: $€ 9,000,000$

Wildau/Technical University of Applied Sciences Wildau (TH Wildau) is located on a small part of the large industrial site of the former Schwartzkopff factory.

Hall 10, a former locomotive shed, was transformed into a library for the university (Figure 1). A great deal has been written about the transformation (Mosig and Seeliger 2008; Niess 2016; Seeliger et al. 2011; Seeliger 2011). This chapter provides a critical review and analysis of various aspects such as spaciousness, accessibility, flexibility and usage. It also addresses the inadequacies as well as the phasing of service development in the library. The intention is to present colleagues and interested readers a report which might be used as stimulus and inspiration for other comparable projects. Open spaces with maximum flexibility herald the future for 
libraries, but the reuse of buildings opens up unexpected potential for atmospheric space utilisation with great appeal to users. In particular, the experience at Wildau shows how a distinctive ambience with a strong character enables librarians and users alike to identify with the space and appreciate it as a high-quality library.

The design for the conversion of Hall 10, the disused locomotive shed, into a university library with a canteen and café was based on an architectural strategy of Weiterbauen/building continuity. The approach is not based on a false romanticism of ruins of a building or overpowering intervention characterised by fashion trends or expressions of functionalism. Weiterbauen focuses on discovering the inherent structural and conceptual underpinning, which define character and meaning, and allows the building's origins, coupled with new requirements, to lead to further growth.

\section{The Wildau Library: The Architect's Perspective}

The Schwartzkopff extensive manufacturing works, built around 1900, was logistically located on the river Dahme and consisted not only of industrial halls for the production of railway tenders and locomotives but also accommodation for the workers, administrators and directors along with buildings for leisure and community facilities. Although the respective buildings were adapted to their functions, almost all, whether industrial or residential, were created in a richly structured brick architectural style with decorative plastered inlays (Figures 1 and 2).

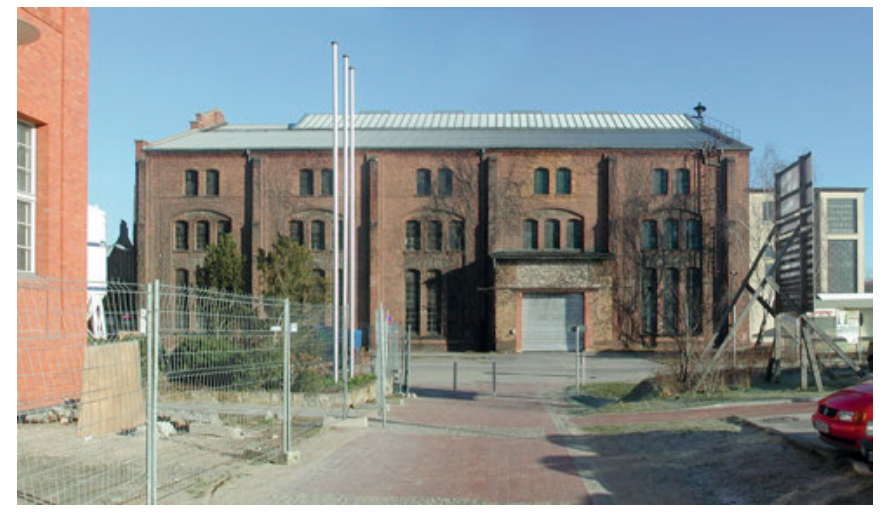

Fig. 2: The exterior of Hall 10 in 2002. (c) Robert Niess.

Hall 10 stands on perhaps the most prominent site of the former manufacturing facility. It was placed on the urban edge formed between the railway line and the housing estate and at the factory's railway station forming a transverse axis. The 
profile of the urban edge is characterised by the large, decorative gables of the workshops, giving the factory a visible and stylistic character. Together with the large administration building, Hall 10 formed a gateway at the train station and was the formal entrance to the factory grounds for workers and visitors (Figure 2).

The original design of Hall 10 dating from 1919/20, was of seven bays although inexplicably only six were realised. The building was never fully completed, and a thin temporary wall was built on its eastern end as weatherproofing. The important gable façade on the urban edge was omitted and the building left faceless.

The longitudinal façades, defined by bays with pillars, cornices and three tripartite tiered windows, suggest on the outside a three-storey structure. Inside, however, was one large space (Figure 6) indicating that the architectural expression of the building was more focused on the tectonic volume and formal façade structuring and less on the content or function of the building. The large open interior is illuminated by the stacked side windows and a large skylight, imparting a special, almost sacred character. Atypical for a production building, the whitewashed walls and a floor made of fine end grain wood pavers are witnesses to the unusual function of the building as a loading hall. The completed locomotives and tenders were disassembled, packed and loaded to be shipped for worldwide export.
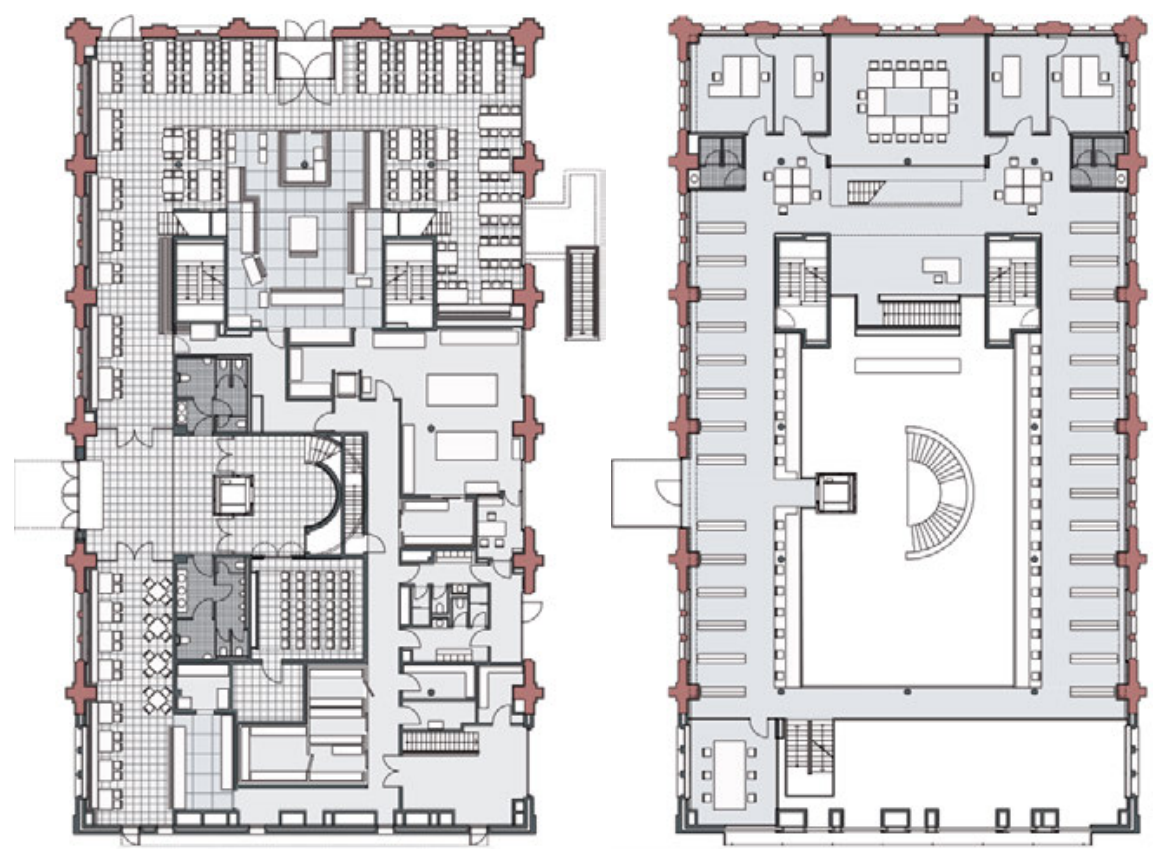

Fig. 3: The ground floor (left) and $3^{\text {rd }}$ floor (right) of the new library. (c) Chestnutt_Niess Architects. 


\section{The Architectural Concept}

Designing an academic library combined with a canteen and café for the university in an existing, listed building was an unusual and complex challenge because several functions not usually expected to be together under one roof were blended.

The design task was viewed as an opportunity for the building to be finally completed, undergoing a metamorphosis almost a century after its original construction. The proposal was to extend the existing building architecturally returning it to its original planned length along with a new gable façade. The gable as an urban face would express the building's new function along the urban edge of the railway embankment.

The architectural language of Weiterbauen/building continuity reflects the original structural ideas behind the existing building and interpretively continues them using modern materials and design. The extension with its new gable were especially designed to give the building an inherent but new architectural expression. The spatial quality, inside and outside, arises from the interplay of its structural epochs and the materials used.

The modern construction consists of a coloured, smooth-surfaced concrete, which, together with the modelling of pillars, cornices and window reveals and extends the previous architectural expression into the present. The coloured concrete was used inside and outside as a visible unifying material and the outer walls were constructed as a sandwich with insulation in-between. A warm-coloured blast furnace cement, dyed with an iron oxide pigment (Bayferrox), was chosen. The light red, slightly brownish colour blends harmoniously with the historic brick architecture and the rust-discoloured surfaces of the railway environment. At the same time, the building is unmistakably articulated as a modern construction. Due to the lively colour, which was created by pouring the dyed concrete on-site, and the smooth, large-format formwork, the raw concrete surfaces appear unusually imposing. The precise demands of the exact in-situ construction of the exposed concrete posed a particular challenge for the small local construction company. Although the craftsmen had little experience in producing such demanding concrete surfaces, there was great interest and understanding of the design requirements, which was shown in the high level of commitment and excellent execution of the work. 


\section{Designing the Library}

The original large space of the locomotive shed served as the basis for the organisation of new functions. Maintaining the ability to perceive and read the original volume of the former space enhanced the historic preservation concept as a duality of old and new. Interestingly, the Renaissance painting St. Jerome in his Study by Antonello da Messina served as an inspiration for conceiving the space. The former large inner space of Hall 10 was seen as a huge house comprising many spaces and rooms, all serving the university. The intention was that the library space would be the innermost room of the campus; the place that remains in memory from student times. It was decided that the innermost room should serve additional purposes beyond the everyday functions of the library.

The canteen and café, served by a common kitchen, as well as a multitude of adjoining spaces were located on the ground floor for logistical reasons (Figure 3). The delivery area was situated on the north side and the common public entrance for both canteen and library oriented to the campus on the south side. The location of the main entrance is the result of an older intervention in the façade constituting both evidence of functionality and witnessing the changes over time.

The library is accessible via the southern entrance and located above the canteen and café on the first floor. A generous curved stair leads the visitor upwards to the main floor of the library, a piano nobile whose orientation provides a view over the campus. An elevator at the entry provides barrier-free circulation for the entire library.

The large library space is arranged on several levels with an atrium underneath and around the opening of the old skylight (Figure 7). The main reading area is on the piano nobile and located on the new gable façade. Lockers, computers and the large information counter are also located on the main floor. The upper floor contains bookshelves, rooms for group work, offices and carrels and reading spaces, orientated towards the atrium (Figure 9).

The central skylight was perhaps the most important source of light for the locomotive hall. It dominates and forms the space and gained significance and symbolic quality in the transformation to the library. Originally following the slope of the roof, the skylight was redefined into a perceptible volume as a generously glazed lantern. The lantern illuminates the interior with natural daylight and shines out in the evening as a symbolic landmark of the library. Also symbolic in an urban context is the architectural expression of the new gable façade. Old plans did not show how the façade was intended, leaving its original design up to speculation and providing an opportunity to expose the library. The new gable includes a large, glazed opening with views into and out of the library (Figure 4). The large opening is divided by several visible supply shafts, the technical nature 
of which was integrated into the new façade like a display case paying homage to the technical nature of the university.

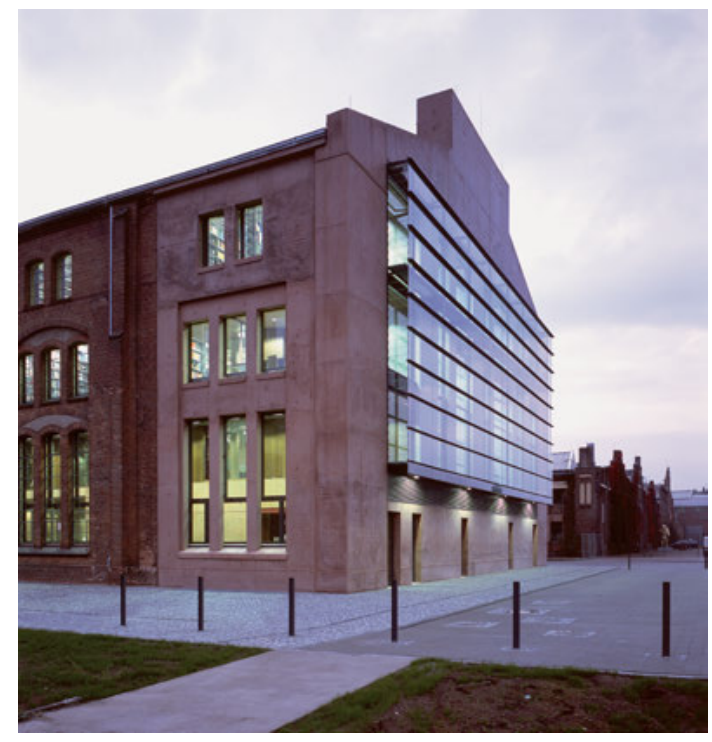

Fig. 4: The extension to Hall 10. (C) Werner Huthmacher.

\section{The Wildau Library: The Librarian's Perspective}

The key requirements underlying the design concept from the library point of view were:

- The library should be a prestige landmark project which would attract attention;

- Users should identify with the building through revisiting its history;

- Choice of location for the new library should emphasise integration into the environment, upgrading the surrounds where necessary;

- Consideration of the pros and cons of reusing a historic building;

- Potential to obtain funding;

- Functionality from a library and user perspective including space allocation, user journeys through the building and climate control.

The library team moved into its new quarters on time for the start of the 2007 winter semester and was immediately impressed with the quality of the new space. It had an instant impact raising the profile of the library and giving the 
staff a new feeling of value and sense of appreciation. The new presence of the library in the listed factory building enhanced an awareness within the university and the general public of just how vital and important an information facility is.

With the new library space and all its possibilities, the library was able to reinvent itself. New beginnings do not appear from nowhere and appear in a different light if one takes into account previous situations. In the sense of HansGeorg Gadamer, the future defines recognition rather than the past: "Future is origin”.

The beginnings of the university library originate with the founding of the Wildau Business School, later Engineering School, in 1949. The school facilities were divided between two locations within the extensive industrial area. The early period of the library, up through German reunification and into the first years after the founding of TH Wildau in 1991, was characterised by temporary locations in spare rooms and different locations.
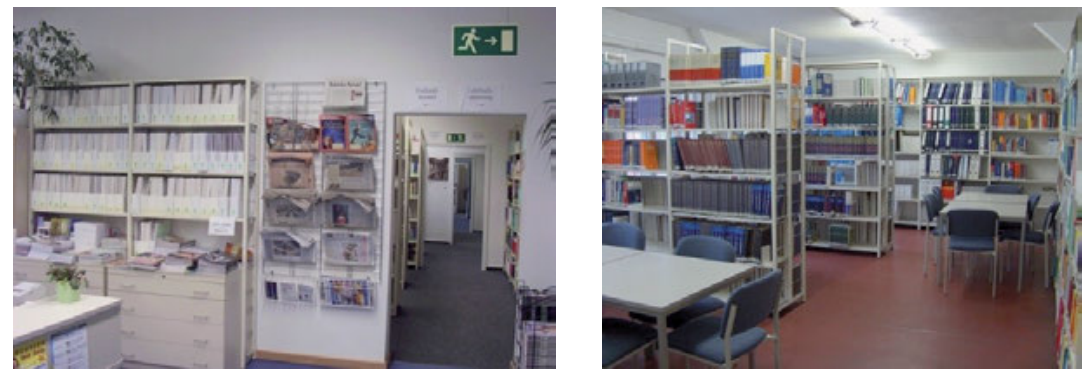

Fig. 5: On the left is the former reading room in Building No. 7 and on the right is shelving in Building No. 13. () Frank Seeliger.

The library was divided and located in Buildings 7 and 13 on two campus locations, about two kilometres apart. Part of the library was in a former chemical factory building for methanol and acetone, nicknamed the Essigbude/Vinegar shed, and comprised a complicated network of small-scale rooms, previously offices, with precarious lighting conditions. The cramped overflowing shelves and linoleum flooring exuded negative charm and were unattractive as places for study and work. Both branches of the library were hidden away in buildings with different functions and largely invisible.

The library team and the faculty were full of hope and anticipation in advance of the move into the new library. The new perspective led Frank Seeliger to accept the position of Director of the new library. With high expectations for the new library, the first question to be addressed before moving into the renovated his- 
toric building, was how to take care of the library and especially how to manage the library over three levels.

To initiate the project, the university compiled a brief, listing all required spaces as well as the need for the building to serve two quite different functions: a large canteen and café for the university as well as the new library. In 2000, planning began for the adaptive reuse of the derelict factory building Hall 10 (Figures 2 and 6), originally built in 1921. The state of Brandenburg hired the office of Chestnutt_Niess Architects, who had experience in designing projects in a historic context, for the prestigious and complex project. The design called for the canteen and café for serving up to four thousand students and staff to be placed on the ground floor and the library to be located on the upper floors.

When the new Director assumed office, the overall planning and most of the construction had already been completed. This was regrettable, as the opportunity to influence the project and change some of the required spaces, for example, to create more storage space in the counter area, was no longer possible. It did, however, mean that input into detailed possibilities and options could be accommodated. Luckily delays in construction provided a welcome opportunity to plan the logistics of the move and to integrate RFID technology which had become available as a security option for the library collections but had not been included in the original planning requirements.

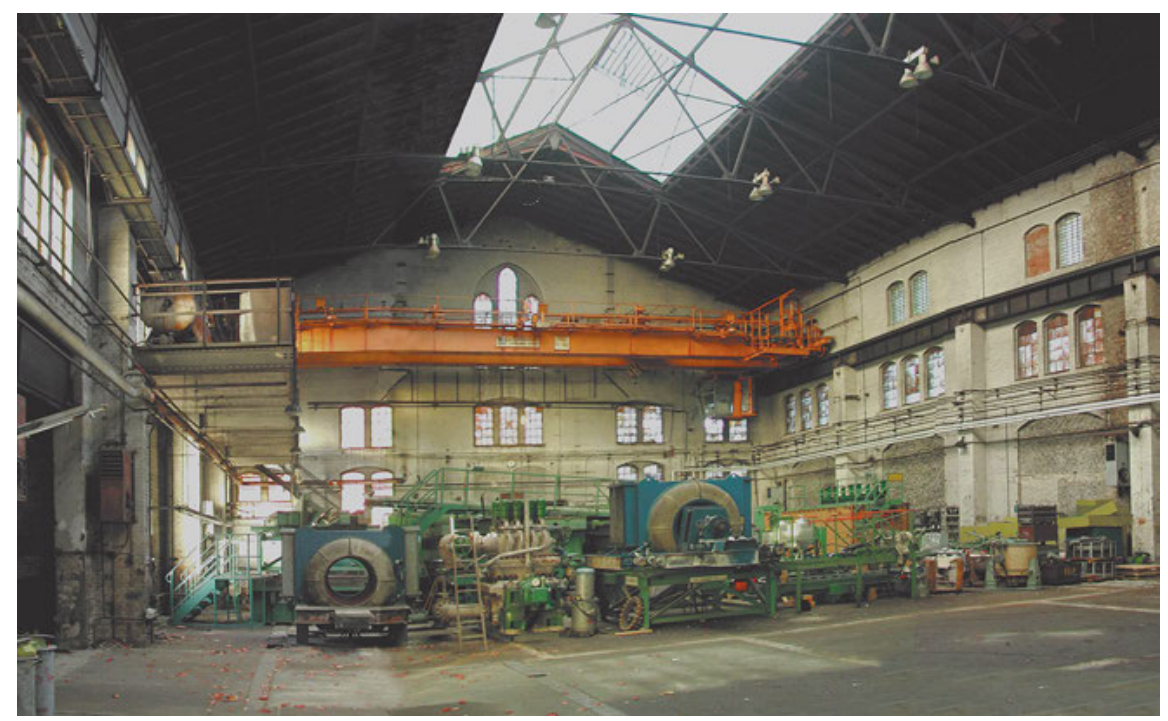

Fig. 6: The interior of the existing building, Hall 10 in 2002. (c) Robert Niess. 


\section{The Beginning Began with the Place}

The librarians longed for the opening of the new library, to furnish it and make it their own. Metaphorically it was akin to making a new cuvee wine, aged in old oak barrels, as an event that calls for special joy and celebration. For the opening celebration, two events, a concert of Carmina Burana and a video installation were performed in the presence of two state ministers. The video, as an art installation, was designed especially for the library space. Titled Just Talk, No Action, it was composed by the New York-based artist Chris Hopkins and performed twice in the library.

The impact of the transition from an inconspicuous makeshift library to a ballroom with cloister-like galleries and private offices was immense. With the doubling of bookshelf capacity and usable space, it felt like climbing onto a prize winner's podium. The destination had been reached, but what now? High expectations come with attaining an overwhelming goal and gaining such a treasure. Do the team and the services on offer fit with an innovative temple of knowledge and live up to its demands? A library strategy that included implementing new measures and taking advantage of all the options available had not been developed. Suddenly, there were spacious aisles between the bookshelves and ample shelf space so that books no longer had to be stacked on top of each other. There was a multitude of modern workplaces and group study rooms, bright offices, a modern information counter, self-service check-out machines based on RFID technology and security gates. What was new and highly significant was that the library occupied the most central and dominant building on campus. Stepping out of the city train arriving from Berlin, the first building encountered is the new library and café in

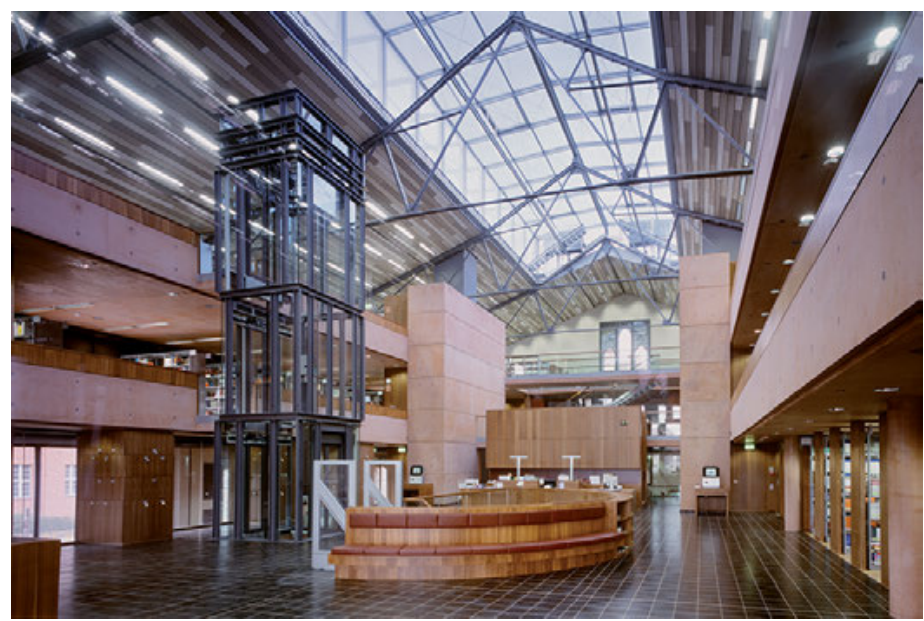

Fig. 7: The central space of the library. (c) Werner Huthmacher. 
Building 10. It is a landmark building with a large glass façade and skylight illuminating the night sky. It is more than attractive; it is magnetic and radiates symbolism and strength. The successful architectural design of a library, both in terms of aesthetics and function, creates a crucial first impression, a calling card. The first impression determines whether a person decides to step inside - or not.

\section{The Space as an Enabler}

Library staff have seen that the library space works effectively and attracts people. Approximately 100,000 visitors, users and customers flock to the temple of the library every year. Contributing to the high usage figures is the fact that the young town of Wildau, a municipality since 2013, offers limited venues for cultural events. Another advantage is that the library is located next to the local train station. There are bus stops nearby and plenty of parking on campus. The team at the canteen and café offers catering at the location. Barrier-free access via the elevator is seen as an advantage, especially for customers with mobility issues. The library has initiated a series of exhibitions of drawings, photographs and other artwork, music events such as the New Year's Day Concert put on by the Lions Club, book presentations and readings as well as special events and much more (Figures 8a, 8b). The library is in high demand for cultural events, but the demand is just as high for scientific and other academic activities.

New colleagues at the university visit the library on induction tours and in preparation for their semester planning. The friendly atmosphere of the library interior quickly wins people over and sparks ideas for future collaboration. Project work demanding close cooperation from all areas of education and research with the library team has become commonplace and includes such activities as producing publications, internship ventures, management of final theses and applications for third-party funding.

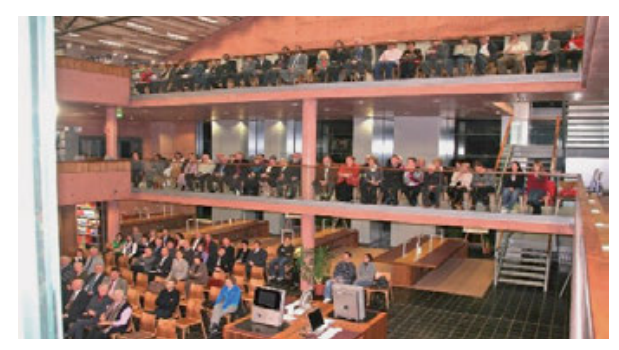

Fig. 8a: Concert in the library. (c) Frank Seeliger.

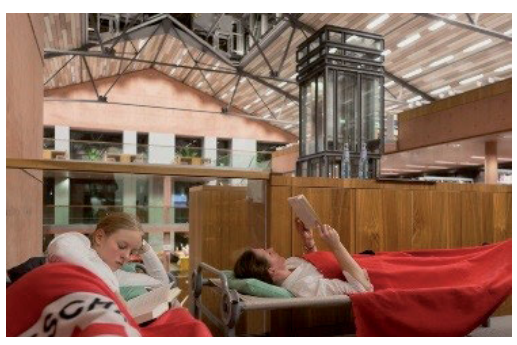

Fig. 8b: Sleepover in 2012. (c) Marcus von Amsberg. 
The library's most frequent project initiator visited the space for the first time over ten years ago after an interview with the search committee for a professorship. The inspiring space of the library impressed her so much that she has worked on projects with the library ever since with successful exchanges of information. It is unlikely that the successful collaboration would have occurred while the library was based in its previous quarters.

\section{A Space Full of Nooks and Crannies}

Events of all types are held on the piano nobile of the library and, similar to the famous Teatro alla Scala in Milan, can be viewed from the two upper floors with excellent visual and acoustic quality. The constellation of stage and spectators is only one option. The main floor offers a total of four further spatial combinations. The spatial variety constantly surprises event organisers because the large spiral staircase situated in the middle of the room is initially perceived as a drawback. The flexibility is particularly appreciated because of the large variation of size and diversity of the audiences. It is possible to create a pleasant atmosphere for an event, whether there are 30 people or over 100 attendees. The special spatial effects would not be possible in a classic auditorium or lecture hall.

Hosting cultural events and festivals is usually a trademark of public libraries rather than academic libraries but the Wildau library has a predestined event location. The library hosts five to ten events every year outside its regular opening hours. Annually there is at least one private viewing of photographs and drawings with easels set up on all floors to present the collected works. Whether it is a performance of Thomas Mann's Confession of the Imposter Felix Krull or A Christmas Carol by Charles Dickens or something else, the combination of stage and scene with accompanying sound and lighting technology is a permanent fixture on the piano nobile of the library.

One event which differs from customary concerts or book readings is the Schmökerabend/Sleepover (Figure 8b) which has taken place several times, with up to one hundred people, predominantly children and teenagers, setting up their beds for the night between the shelves and in various other cosy corners to read favourite children's or teenagers' books. That description tells only half the tale, because the sleepover also feels like an indoor playground, with a paper airplane contest from the upper tiers to boot. 


\section{Extraordinary Usage}

The magnetic appeal of the library space has led to its adoption as the university's living room. The library is used at times by people simply looking for an agreeable indoor atmosphere which sometimes hinders the library's fulfilment of its primary role and core task of being a collection-focused place of learning and a workplace for students. Nonetheless, discussion evenings such as the series In Conversation with Leading Politicians, Brandenburg state receptions on occasions like the International Aerospace Exhibition, receptions of leading private sector companies, information events, television recordings, chess tournaments and other similar events are inspirational and make the library a vital part of the university and the community.

It is a credit to the university management and library staff that the extraordinary uses of the library have enhanced both the library and the university but have not become the norm. It has remained possible to maintain the library space essentially free for its intended use as the central learning and research space for the university.

\section{The Disadvantages of a Heritage Building}

There are some limitations in the use of the library space. Even though three hundred people could easily fit into the library, the largest number permitted at any given time is limited to 199. The library was not designed to meet the strict building code for large public gatherings. Furthermore, the large and open central space which is suitable for events and provides an atmosphere conducive to social learning, does not support the quiet learning atmosphere which might be expected in the classic academic reading room. The hard flooring of the piano nobile amplifies the ambient noises from the information desk, discussion between users and noise from the locker area. Many people find the background noise during rush hour at lunchtime disruptive. The disadvantage is partially offset by the provision of a limited number of group study rooms.

Another challenge is the large skylight. The glass roof spans the entire central courtyard area and allows for good lighting conditions all year round (Figure 7). Unfortunately, not all the planning aspects, which called for an indirect light reflective system in the glazing, were implemented. During the hotter months of the year when the weather is sunny, compromises must be made in relation to the information desk and the workstations on the north side of the building that are directly in the sun in the morning and subject to glare. There is a strong contrast 
between light and dark surfaces. After twelve years and a plethora of discussions with all involved, as well as expert opinions and reports, the only apparent solution is to redesign the glazing system as originally planned.

The last problem is the indoor temperature which, due to noticeably warmer summers, has increased in recent years. The library does not have air conditioning, and the originally planned cooling integrated in the concrete was deleted from the project during the construction phase as a cost reduction. As a result, temperatures of well over 30 and even up to $40 \mathrm{C}$ have been measured on all three floors and in the offices from June onwards. Automated cross ventilation at night has helped, but the air turnover is extremely low due to the small outlet openings.

One last important point relates to the upkeep of the facility. Although the facility has been thoroughly and regularly cleaned and maintained since its opening in 2007, wear and tear are evident in several areas despite regular repairs and touching up. It is important to maintain the image. Users stay an average of four hours daily in the Wildau library and to continue to attract people and encourage them to stay within the building, the library must be clean, modern and fresh with everything in tip-top condition. Modernisation and alterations, which are necessary to maintain a cutting-edge library, represent a constant bureaucratic challenge. As an example, a new library desk, designed in 2014 by the architect in cooperation with the library team, is scheduled for implementation in 2022!

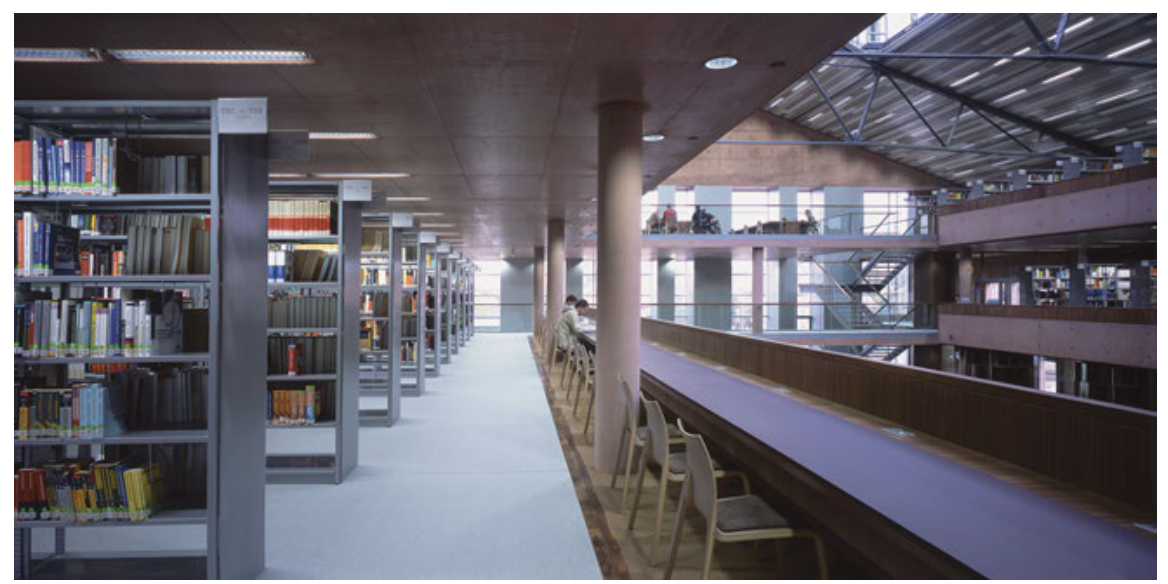

Fig. 9: The upper levels of the library. (c) Werner Huthmacher. 


\section{Managing and Organising Change}

The use of the library has changed tremendously. Four key aspects are:

- Reduction in the number of printed books on the open shelves

- New information technology requiring new infrastructure

- Growth in staff numbers

- Unrestricted use regardless of official opening hours or staff presence.

Except for certain specialist libraries, the importance and presence of printed works has declined, due to the increased availability of e-books, e-journals and databases. Multiple copies of book titles or editions are disappearing and most journals and periodicals are offered only online. The changes have affected the library at TH Wildau. For example, bookshelves holding the textbook collection on the piano nobile were removed in 2019. The space, with parquet timber flooring and wooden dividers, is being changed into a reading lounge. In the foreseeable future, as print collections are reduced further, more shelving can be removed and additional learning and workspaces provided.

In the early days the library was proud of its forty computers equipped with thin clients and other devices. Today, users tend to bring their own devices. Not only do the devices need to be recharged at electrical outlets, but the positioning of Bluetooth, wireless and other ICT devices is complex. Maintaining rechargeable batteries in a mobile newspaper shelf using RFID technology to count the number of users taking newspapers from the shelf is challenging. The demand for a flexible power supply has increased tremendously. If there were more wall or in-floor outlets, a master key system including chip or smart cards for the lockers could be integrated. Moreover, through the analysis of the chip card and potentially the RFID readers, real-time usage could more accurately be determined, and fluid and unrestricted library usage could be optimised. Large touch screens could be made available close to the information desk and in one of the group rooms. Wireless internet is ubiquitous, and people can access the internet from almost anywhere, but sometimes a connection to a power supply network is rare.

In the beginning, the library was well provided with staff workspaces. There were four offices accommodating two to three people in each, a front desk with three work areas and a small kitchen. Now the offices are crowded, even though staff can telework. An increased number of staff and positions due to part-time work, project work, trainees, student assistants and internships has meant that some employees overflow into the media centre.

The last major change introduced was in May 2018 with faculty, students and staff able to use the open space of the library $24 / 7$. There was a learning curve before the service could be implemented. Approximately 700 people, mostly stu- 
dents, signed up and were instructed by a humanoid robot who enabled them to enter the library independent of opening hours using individual chip cards. Use of the library as a learning resource centre has increased. It is very seldom that no one is in the library, and during exam periods and at weekends, there are hundreds of users in the library.

\section{Conclusion}

The great success of the TH Wildau Library is undoubtedly due to its astonishing architecture. The peak was reached in 2012 when it won the German Library of the Year Award. After over ten years of hard work, the library staff can justifiably say that they turned the jewel of a library into something even more special. With the services on offer, everyone can proudly say that justice has been done to the fantastic building. Perhaps library staff went above and beyond expectations knowing that they were blessed with a totally reliable asset: the wonderful library space.

\section{References}

Mosig, Susanne, and Frank Seeliger. 2008. "In der Werkhalle des Wissens: Die Bibliothek der Fachhochschule Wildau ist in denkmalgeschützten Industriebau umgezogen." BuB: Forum für Bibliothek und Information 60 (2): 149-54. https://www.b-u-b.de/pdfarchiv/ Heft-BuB_02_2008.pdf\#page=1\&view=fit\&toolbar=0\&pagemode=bookmarks

Niess, Robert. 2016. "Bibliotheksbau im Bestand, oder: Die Liebe zum Unikat.” In Praxishandbuch Bibliotheksbau, edited by Petra Hauke and Klaus Ulrich Werner, 113-23. Berlin/Boston: De Gruyter Saur.

Seeliger, Frank, ed. 2016. Auf den Spuren der Wildauer Steine: Ein Architekturspaziergang. $2^{\text {nd }}$ ed. Berlin: Verlag News \& Media.

Seeliger, Frank, Robert Niess, and Mario Weigt. 2011. "Die Spur der Wildauer Steine: Industrierelikt im Zeitenstrom: Vom Wandel einer Fabrikruine zur modernen Hochschulbibliothek." In Bibliotheken heute!: Best Practice in Planung, Bau und Ausstattung, edited by Petra Hauke and Klaus Ulrich Werner, 54-69. Bad Honnef: Bock + Herchen. https://edoc.hu-berlin.de/handle/18452/2885

Seeliger, Frank. 2011. "Chancen und Risiken einer baulichen Konversion: Oder: Gibt es einen patinierten Erlebnisraum Bibliothek." In Secondhand - aber exzellent!: Bibliotheken bauen im Bestand, edited by Petra Hauke and Klaus Ulrich Werner, 46-59. Bad Honnef: Bock + Herchen. https://edoc.hu-berlin.de/handle/18452/2918 